\title{
Peningkatan Pengetahuan Gizi Siswa Kelas 5 SD ABATA Islamic School tentang Keamanan Makanan Jajanan
}

\author{
Ratnayani $^{1}$, Gusti Kumala Dewi ${ }^{2}$, Vera Kasmira ${ }^{3}$, Ina Ratnawati ${ }^{4}$ \\ ${ }_{1,2,3,4}$ Program Studi Gizi, Universitas Binawan \\ Email: ratnayani1105@binawan.ac.id
}

Submitted : 22/09/2021

Accepted: 16/10/2021

Published: 19/11/2021

\begin{abstract}
An Elementary school (SD) children are one of the main targets of street food vendors. These snacks provide energy and some nutrients for those who consume it. However, there are things to be alert from street food, especially in terms of food safety. There are still many street food that made using food additives (colourings, sweeteners, preservatives, etc.) that do not meet the requirements. This can cause poisoning and even Extraordinary Events. Based on this, it is necessary to provide education about street food for elementary school children so that they can choose the healthy street food. Given the unfavorable situation, education is conducted online through Google Meet (Gmeet). The theme raised in this education is "Great Children Have Healthy Snacks" and the targets are 5th graders at ABATA Islamic School Elementary School, Karawang. The education event was carried out twice, on January 14 and 21, 2021. To find out whether the participants had understood the material presented, a pre-test and post-test were conducted. This activity has increased students' nutritional knowledge. This can be seen from the average post-test score which is higher than the pre-test.
\end{abstract}

Keywords: elementary school children, food additive, food safety, street food

\begin{abstract}
Abstrak
Anak usia Sekolah Dasar (SD) merupakan salah satu target utama dari para pedagang makanan jajanan. Makanan jajanan ini memberikan sumbangan energi dan beberapa zat gizi bagi yang mengkonsumsinya. Namun terdapat hal yang perlu diwaspadai dari makanan/minuman jajanan ini terutama dari sisi keamanan pangan. Masih banyak makanan jajanan yang dibuat dengan menggunakan bahan tambahan pangan (pewarna, pemanis, pengawet dll) yang belum memenuhi syarat. Hal ini dapat menyebabkan terjadinya keracunan bahkan Kejadian Luar Biasa. Berdasarkan hal tersebut, perlu dilakukan edukasi mengenai makanan jajanan pada anak SD agar dapat memilih makanan jajanan yang sehat. Mengingat situasi yang belum kondusif, penyuluhan dilakukan secara daring melalui google meet (Gmeet). Tema yang diangkat pada penyuluhan ini adalah "Anak Hebat Jajannya Pasti Sehat" dan target sasarannya adalah anak kelas 5 SD ABATA Islamic School, Karawang. Penyuluhan dilakukan dua kali yaitu pada tanggal 14 dan 21 Januari 2021. Untuk mengetahui apakah peserta sudah memahami materi yang disampaikan, maka dilakukan pre test dan post test. Kegiatan penyuluhan ini telah meningkatkan pengetahuan gizi siswa. Hal ini dapat dilihat dari rerata nilai post test yang lebih tinggi dibandingkan pre test.)
\end{abstract}

Kata Kunci: anak usia sekolah dasar, bahan tambahan pangan, keamanan pangan; makanan jajanan

\section{PENDAHULUAN}

Food Agricultural Organization (FAO) mendefinisikan pangan jajanan sebagai makanan dan minuman yang dipersiapkan dan dijual oleh pedagang kaki lima di jalanan dan tempat-tempat umum lainnya yang langsung dikonsumsi tanpa pengolahan atau dipersiapkan lebih lanjut (FAO, 2009). Pangan jajanan anak sekolah (PJAS) umumnya dikenal sebagai pangan siap saji yang ditemui di lingkungan sekolah dan secara rutin dikonsumsi oleh sebagian besar anak sekolah (Gizi et al., 2011). 
Anak Sekolah Dasar (SD) merupakan target sasaran para pedagang jajanan. Berdasarkan Laporan Akhir Hasil Monitoring dan Verifikasi Profil Keamanan PJAS Nasional tahun 2008, menunjukkan bahwa $98,9 \%$ anak jajan di sekolah dan hanya $1 \%$ yang tidak pernah jajan (BPOM, 2013).

Pangan jajanan memegang peranan penting dalam pemenuhan kebutuhan gizi anak. Konsumsi makanan jajanan pada anak dapat memberikan kontribusi $30.0 \%$ dan $22.3 \%$ terhadap kecukupan energi dan protein. Tambahan energi pada saat sekolah bisa berdampak positif kepada anak sekolah. Anak bisa menjadi tetap aktif karena kadar gula darah tetap terjaga dengan baik. Dengan demikian makanan jajanan, khususnya jajanan yang sehat, dapat bermanfaat dan berdampak baik bagi kesehatan (Harikedua et al., 2015).

Namun terdapat beberapa hal yang perlu diwaspadai terkait keamanan pangan jajanan yang beredar. Permasalahan keamanan pangan jajanan erat kaitannya dengan kontaminasi oleh mikroba dan juga penggunaan Bahan Tambahan Pangan (BTP) yang tidak memenuhi syarat. Penelitian mengenai kualitas makanan jajanan anak SD di Kecamatan Koto Tengah, Sumatera Barat menunjukkan bahwa pangan jajanan telah terkontaminasi bakteri $E$. coli dan $S$. aureus (Rahmawita et al., 2018). Penelitian lain di Kabupaten Bantul pada tahun 2016 juga menunjukkan bahwa terdapat 2,93\% makanan jajanan yang mengandung boraks, $1,34 \%$ mengandung formalin, dan $1,02 \%$ mengandung rhodamine-B (Paratmanitya \& Veriani, 2016).

Selain kontaminasi mikroba, penyalahgunaan bahan kimia berbahaya merupakan salah satu masalah utama dalam pangan jajanan. Hasil uji pada program pengawasan PJAS menunjukkan bahwa sampel pangan yang paling tidak memenuhi syarat secara berturut-turut adalah minuman berwarna/sirup, minuman es, jelly/agar- agar, dan bakso. Penyebab sampel tidak memenuhi syarat antara lain karena menggunakan bahan berbahaya yang dilarang untuk pangan, menggunakan bahan tambahan pangan melebihi batas maksimal, dan menandung cemaran logam berat melebihi batas maksimal (Kementrian Kesehatan RI, 2015).

Pangan jajanan yang tidak memenuhi syarat keamanan pangan dapat menyebabkan terjadinya keracunan bahkan Kejadian Luar Biasa (KLB). Laporan mengenai KLB keracunan pangan tahun 2014 menunjukkan bahwa 25,53\% KLB disebabkan oleh pangan jajanan dan $10,64 \%$ disebabkan oleh pangan olahan (BPOM, 2013).

Pada masa pandemi Covid-19, meskipun sekolah diselenggarakan secara daring, namun anak-anak tetap harus terpenuhi kebutuhan gizinya. Penyediaan makanan terutama makanan selingan tetap disediakan oleh orangtua, baik dibuat sendiri, membeli secara online maupun membeli di tukang jajanan yang lewat. Sehingga pengetahuan dan pemahaman mengenai jenis dan keamanan pangan jajanan tetap harus diperhatikan.

Anak kelas 5 SD merupakan periode perkembangan dimana anak sudah mulai mulai berpikir secara hipotetis, mempertimbangkan sejumlah kemungkinan, dan mampu berpikir logis. Sehingga sangat mungkin untuk diberikan pemahaman mengenai sesuatu dalam hal ini pengetahuan mengenai jajanan sehat.

Kelompok anak usia sekolah dasar (SD) merupakan salah satu sasaran bagi para penjual pangan jajanan. Para penjual pangan jajanan, menjajakan dagangannya, tidak hanya di sekolah, tapi juga di lingkungan tempat tinggal. Sehingga meskipun sekolah sedang melaksanakan program pembelajaran secara daring, para penjual pangan jajajanan tetap berjualan di lingkungan tempat tinggal dan menyasar anak-anak usia SD. 
Terkait keamanan pangan jajanan yang beredar, masih belum bisa dikendalikan sepenuhnya. Beberapa hasil survey menunjukkan masih banyak pangan jajanan yang tidak memenuhi persyaratan, terutama dalam penggunaan Bahan Tambahan Pangan (BTP). Sehingga masih banyak anak usia SD sebagai konsumen yang terpapar pangan jajanan berbahaya. Oleh karena itu sangat penting bagi naka untuk memilih makanan jajanan yang sehat agar tetap terjaga dari keracunan makanan (Nurbiyati \& Wibowo, 2014).

Berdasarkan hal-hal tersebut, peneliti menyadari pentingnya makanan jajanan untuk memenuhi kebutuhan gizi anak sekolah. Namun perlu diperhatikan tingkat keamanan makanan jajanan yang diperjualbelikan. Oleh sebab itu, perlu dilakukan edukasi, dalam hal ini kepada anak sekolah sebagai konsumen pangan jajanan. Edukasi yang dilakukan berupa penyuluhan online kepada anak kelas 5 SD ABATA Islamic School, Karawang. Tema yang diangkat pada penyuluhan ini adalah "Anak Hebat Jajannya Pasti Sehat".

Dengan dilakukannya kegiatan ini diharapkan akan terjadi perbaikan sikap anak-anak sekolah dalam memilih makanan jajanan. Penelitian yang dilakukan pada anak SD di Manado dan Bengkulu yang menunjukkan terdapat hubungan antara pengetahuan gizi dengan konsumsi makanan jajanan (Negeri et al., 2019; Nurhastuti, 2019).

\section{TARGET DAN LUARAN}

Sasaran dalam pengabdian masyarakat ini adalah siswa kelas 5 SD ABATA Islamic School Karawang. Diharapkan dengan adanya penyuluhan mengenai makanan jajanan ini, anak-anak dapat memahami dan memilih makanan jajanan yang sehat dan bermanfaat bagi tubuhnya.

\section{METODE PELAKSANAAN}

Kegiatan pengabdian masyarakat ini dilaksanakan di SD ABATA Islamic School, Karawang Jawa Barat. Target kegiatan ini adalah siswa kelas 5 SD. Kegiatan dilaksanakan dua kali yaitu pada tanggal 14 dan 21 Januari 2021. Pelaksanaan kegiatan dilakukan dengan memberikan materi intervensi melalui penyuluhan/edukasi secara online melalui Google meet (Gmeet).

Materi yang diberikan meliputi: gizi seimbang untuk anak sekolah, Jenis-jenis pangan jajanan, dan Bahan berbahaya dalam pangan jajanan serta akibatnya. Materi penyuluhan dibuat dalam bentuk Power Point yang menarik. Untuk mengetahui pemahaman peserta terhadap materi yang disampaikan, maka dilakukan pre-test pada awal acara dan post-test setelah materi disampaikan.

Tahapan Penyuluhan

1. Pembukaan dan perkenalan oleh tim penyuluh

2. Pemberian pre-test kepada peserta berupa pertanyaan seputar materi yang akan diberikan

3. Pemberian materi oleh penyuluh (dosen dan mahasiswa)

4. Pemberian post-test kepada peserta berupa pertanyaan seputar materi yang sudah diberikan

5. Sesi tanya jawab

6. Pemberian doorprize kepada peserta

\section{HASIL DAN PEMBAHASAN}

Kegiatan pengabdian masyarakat dilaksanakan pada tanggal 14 Januari dan 21 Januari 2021 secara online melalui google meet. Peserta kegiatan ini adalah siswa kelas 5 SD Abata Islamic School Karawang dengan usia 10-11 tahun. Jenis kelamin peserta kegiatan dapat dilihat pada Tabel 1 . 
Tabel 1. Jenis Kelamin Siswa SD Abata Islamic School, Karawang

\begin{tabular}{|c|c|c|c|c|}
\hline \multirow{2}{*}{$\begin{array}{c}\text { Jenis } \\
\text { Kelamin }\end{array}$} & \multicolumn{2}{|c|}{ Sesi I } & \multicolumn{2}{|c|}{ Sesi II } \\
\hline & $\mathrm{n}$ & $\%$ & $\mathrm{~N}$ & $\%$ \\
\hline Laki-laki & 18 & 47,3 & 15 & 55,5 \\
\hline Perempuan & 20 & 52,7 & 12 & 45,5 \\
\hline Total & 38 & 100 & 27 & 100 \\
\hline
\end{tabular}

bahwa pada sesi I, kegiatan ini diikuti oleh 38 siswa terdiri atas 18 siswa laki-laki dan 20 siswa perempuan sedangkan kegiatan pada sesi II di ikuti oleh 27 siswa, terdiri atas 15 siswa laki-laki dan 12 siswa perempuan.

Pada umumnya anak sekolah memiliki kebiasaan mengkonsumsi jajanan berkalori tinggu dan rendah serat, sehingga rentan terjadi masalah gizi seperti kegemukan atau obesitas. Jajan merupakan hal yang diasa dilakukan oleh anak-anak, khususnya anak sekolah. Pada satu sisi jajan mempunyai aspek yang positif, namun disisi lain jajan juga bisa memiliki makna yang negatif. Jajan dapat diartikan makan diantara rentang waktu makan pagi dan makan siang yang relatif panjang, sehingga anak-anak memerlukan asupan gizi tambahan diantara kedua waktu tersebut (Ari Istiany and Rusilanti, 2013).

Pada usia sekolah 6-12 tahun, secara bertahap terjadi pendewasaan keterampilan seperti kognitif, sosial dan emosional serta memperoleh keterampilan yang memungkinkan mereka mengembangkan kesukaan makanannya sendiri secara bebas dan membentuk kebiasaan makan (Almatsier et al., 2011). Oleh karena itu, pada rentang usia ini dapat diberikan edukasi khususnya edukasi gizi. Kegiatan ini dilakukan selain untuk menambah pengetahuan gizi siswa juga diharapkan akan terjadi perubahan kebiasaan jajan menjadi lebih baik.

Edukasi gizi yang diberikan kepada para siswa ini dilakukan dalam dua tahap.
Pada tahap I disampaikan 2 materi yaitu mengenai gizi seimbang dan jenis-jenis makanan jajanan. Pada tahap II materi yang disampaikan yaitu mengenai bahan-bahan berbahaya pada makanan jajanan.

Edukasi gizi ini berisikan materi tentang gizi seimbang jenis makanan jajanan dan bahan berbahaya pada makanan jajanan. Selama penyuluhan berlangsung peserta dengan seksama memperhatikan setiap materi penyuluhan yang diberikan. Hal itu terlihat ketika sesi tanya jawab peserta yang disampaikan melalui kolom chat room, banyak antusias pertanyaan yang diajukan oleh peserta penyuluhan.

Untuk mengetahui apakah terjadi perubahan pengetahuan mengenai materi yang disampaikan, dilakukan pretest dan post test. Kegiatan pretest dilaksanakan sebelum materi disampaikan dan post test dilakukan setelah materi dan diskusi selesai dilaksanakan. Pengisian soal pretest dan post test dilakukan selama 10 menit. Hasil pretest dan post test sesi I dan II dapat dilihat pada Tabel 2 dan Tabel 3.

Tabel 2. Hasil Pre Test dan Post Test Sesi I

\begin{tabular}{ccccc}
\hline Test & Min & Max & $\begin{array}{r}\text { Rata- } \\
\text { Rata }\end{array}$ & $p$ \\
\hline Pre Test & 37,5 & 100 & 65,9 & 0,613 \\
Post Test & 37,5 & 100 & 67,6 & \\
\hline
\end{tabular}

Tabel 3. Hasil Pre Test dan Post Test Sesi II

\begin{tabular}{ccccc}
\hline Test & Min & Max & $\begin{array}{c}\text { Rata- } \\
\text { Rata }\end{array}$ & $\mathrm{p}$ \\
\hline Pre Test & 12,5 & 100 & 61,5 & 0,438 \\
Post Test & 37,5 & 100 & 65,6 & \\
\hline
\end{tabular}


Hasil analisa tabel diatas menunjukkan bahwa skor rata-rata tingkat pengetahuan sebelum diberikan penyuluhan (Pretest) yaitu 65.9, sedangkan setelah diberikan penyuluhan (post test) yaitu 67.6. Berdasarkan uji Mann whitney tidak adanya perbedaan signifikan nilai pengetahuan antara sebelum diberikan penyuluhan dan sesudah diberi penyuluhuan.

Pada tahap II jumlah peserta yang mengikuti kegiatan webinar yaitu 27 orang. Jumlah ini lebih sedikit dibandingkan dengan tahap I karena adanya jadwal pembelajaran yang bersamaan dengan jadwal pengabdian masyarakat, sehingga beberapa siswa berhalangan hadir. Hasil analisis pretest dan post test tahap II dapat dilihat pada Tabel 3. Skor rata-rata tingat pengetahuan pada saat pretest adalah 61,5. Meskipun secara statistik tidak ada perbedaan signifikan, tetapi terjadi kenaikan rata-rata tingkat pengetahuaan pada saat post test menjadi 65,6 .

Pada tahap I dan II terjadi perbaikan nilai tingkat pengetahuan gizi pada siswa yang telah diberikan penyuluhan mengenai makanan jajanan. Peningkatan pengetahuan gizi ini diharapkan dapat memberikan perubahan pola konsumsi terutama dalam pembelian dan konsumsi makanan jajanan.

\section{KESIMPULAN DAN SARAN}

\section{Kesimpulan}

Pengabdian masyarakat berupa penyuluhan online kepada siswa kelas 5 SD ABATA Islamic school karawang mengenai makanan keamanan makanan jajanan telah meningkatkan pengetahuan gizi siswa. Hasil ini sesuai dengan tujuan dan target dari pengabdian masyarakat.

\section{Saran}

Pada saat pembelajaran sudah dilakukan secara tatap muka, sebaiknya sekolah juga memberikan penyuluhan kepada pedagang makanan jajanan di depan gerbang sekolah untuk menjajakan makanan yang sehat.

\section{UCAPAN TERIMAKASIH}

Terimakasih kepada LPPM Universitas Binawan yang telah memberikan hibah sehingga pengabdian kepada masyarakat dapat terlaksana.

\section{DAFTAR PUSTAKA}

Almatsier, S., Soetardjo, S., \& Soekatri, M. (2011). Gizi Seimbang Dalam Daur Kehidupan. PT Gramedia.

Ari Istiany and Rusilanti. (2013). Gizi Terapan. PT Remaja Rosidakarya.

BPOM. (2013). Pedoman Pangan Jajanan Anak Sekolah untuk Pencapaian Gizi Seimbang. Direktorat Standardisasi Produk Pangan Deputi Bidang Pengawasan Keamanan Pangan Dan Bahan Berbahaya Badan Pengawas Obat Dan Makanan Republik Indonesia, 37.

http://standarpangan.pom.go.id/dokum en/pedoman/Buku_Pedoman_PJAS_u ntuk_Pencapaian_Gizi_Seimbang__Or ang_Tua_Guru_Pengelola_Kantin_. pdf

Gizi, D. B., Bina, D., Dan, G., Ibu, K., Anak, D. A. N., \& Ri, K. K. (2011). Keamanan Pangan.

Hari kedua, V. T., Legi, N. N., \& ... (2015). Kontribusi Makanan Jajanan terhadap Total Energi dan Status Gizi Pada Anak Sekolah di SD Inpres Buku Kecamatan Belang. Jurnal ..., 7(1). https://ejurnal.poltekkesmanado.ac.id/index.php/gizi/article/do wnload/62/50

Kementrian Kesehatan RI. (2015). Situasi Pangan Jajanan Anak Sekolah. In Pusat Data dan Informasi (pp. 1-6).

Negeri, D., Manado, K., Wowor, P., Engkeng, S., \& Kalesaran, A. F. C. (2019). Faktor-Faktor Yang Berhubungan Dengan Perilaku Konsumsi Jajanan Pada Pelajar Di Sekolah Dasar Negeri 16 Dan Sekolah 
Dasar Negeri 120 Kota Manado.

Kesmas, 7(5).

Nurbiyati, T., \& Wibowo, A. H. (2014).

Pentingnya Memilih Jajanan Sehat.

Jurnal Inovasi Dan Kewirausahaan, 3(3), 192-196.

https://journal.uii.ac.id/ajie/article/vie

w/7832

Nurhastuti. (2019). Pengaruh Pendidikan

Kesehatan Terhadap Sikap dan

Frekuensi Konsumsi Makanan Jajanan.

Jurnal Kesmas Asclepius, 1, 1-13.

Paratmanitya, Y., \& Veriani, A. (2016).

Kandungan bahan tambahan pangan

berbahaya pada makanan jajanan anak

sekolah dasar di Kabupaten Bantul.

Jurnal Gizi Dan Dietetik Indonesia

(Indonesian Journal of Nutrition and

Dietetics), 4(1), 49.

https://doi.org/10.21927/ijnd.2016.4(1)

$.49-55$

Rahmawita, R., Putri, D. H., \& Advinda, L.

(2018). Kualitas Jajanan Anak Sekolah

Dasar Secara Mikrobiologi Di

Kecamatan Koto Tangah Padang

Sumatera Barat. Biomedika, 10(2),

102-106.

https://doi.org/10.23917/biomedika.v1

0i2.7020 